\title{
Article \\ Preparation, Characterization and Evaluation of Guar Films Impregnated with Relaxing Peptide Loaded into Chitosan Microparticles
}

\author{
Patrícia Batista ${ }^{1,2, *}$, Pedro M. Castro ${ }^{2}$, Ana Raquel Madureira ${ }^{2}$, Bruno Sarmento ${ }^{3,4,5}$ and Manuela Pintado ${ }^{2}$ \\ 1 Research Centre for Human Development, HNL/CEDH—Human Neurobehavioral Laboratory, \\ Universidade Católica Portuguesa, Rua de Diogo Botelho 1327, 4169-005 Porto, Portugal \\ 2 CBQF-Centro de Biotecnologia e Química Fina-Laboratório Associado, Escola Superior de Biotecnologia, \\ Universidade Católica Portuguesa, Rua Diogo Botelho 1327, 4169-005 Porto, Portugal; \\ pcastro@porto.ucp.pt (P.M.C.); rmadureira@ucp.pt (A.R.M.); mpintado@ucp.pt (M.P.) \\ 3 i3S-Instituto de Investigação e Inovação em Saúde, Universidade do Porto, Rua Alfredo Allen 208, \\ 4200-135 Porto, Portugal; bruno.sarmento@ineb.up.pt \\ 4 INEB-Instituto Nacional de Engenharia Biomédica, Universidade do Porto, Rua Alfredo Allen 208, \\ 4200-135 Porto, Portugal \\ 5 CESPU, Instituto de Investigação e Formação Avançada em Ciências e Tecnologias da Saúde, \\ Rua Central de Gandra 1317, 4585-116 Gandra, Portugal \\ * Correspondence: pbatista@ucp.pt
}

Citation: Batista, P.; Castro, P.M.; Madureira, A.R.; Sarmento, B.; Pintado, M. Preparation,

Characterization and Evaluation of Guar Films Impregnated with Relaxing Peptide Loaded into Chitosan Microparticles. Appl. Sci. 2021, 11, 9849. https://doi.org/ 10.3390/app11219849

Academic Editor: Chiara Cavaliere

Received: 27 September 2021

Accepted: 18 October 2021

Published: 21 October 2021

Publisher's Note: MDPI stays neutral with regard to jurisdictional claims in published maps and institutional affiliations.

Copyright: (c) 2021 by the authors. Licensee MDPI, Basel, Switzerland. This article is an open access article distributed under the terms and conditions of the Creative Commons Attribution (CC BY) license (https:// creativecommons.org/licenses/by/ $4.0 /)$.
Abstract: Background: Biological molecules such as therapeutic proteins and peptides have provided ample opportunities for further improvements in health and wellbeing. However, such biomacromolecules face stability challenges regarding premature processing and digestion, whenever any enteric delivery route is considered. Hence, oral guar films entrapping peptide-containing chitosan microparticles have been developed as a new delivery system to carry and protect therapeutic relaxing peptides. Results: The composite films were characterized regarding physicochemical properties using FTIR as well as peptide encapsulation efficiency, cytotoxicity, and peptide permeability through buccal and intestinal cell-based models. The composite films with $0.18 \%(w / w)$ of peptide demonstrated ca. $0.63 \%$ of peptide loading efficiency into the chitosan microparticles and to be safe for buccal and intestinal epithelial cells up to $24 \mathrm{~h}$ of contact. The permeability assays through TR146 cells to mimic buccal mucosa epithelium and Caco-2/HT29-MTX to mimic duodenum conditions showed that the incorporation of peptide chitosan microparticles into guar-gum oral films offered a faster permeability, when compared with the free peptide and peptide-chitosan-microparticles-loaded chitosan. Conclusion: This study suggests that peptide-loaded chitosan microparticles into guar-gum oral films might be a promising carrier for enhancement of the buccal and intestinal absorption of a relaxing peptide.

Keywords: bioactive peptides; oral delivery system; chitosan; oral films

\section{Introduction}

Oral administration of drug delivery drugs is the most popular route, and different dosage forms have been developed for the oral cavity. Oral films offer advantages such as small size and thickness, administration without water, potential rapid onset of action, and overall high convenience of administration [1]. Films have been proved to be suitable to incorporate and promote a sustained release of several bioactive molecules and therapeutic agents [2]. Oral films are generally prepared from a polymeric matrix, which may be composed of one or more polymers. Guar gum is one of the polymers that can be used, being a water-soluble polysaccharide, biodegradable, and a hydrophilic matrix carrier for oral delivery drugs [3-7]. However, proteins and peptides are complex macromolecules that can change their native structure, since they are susceptible to denaturation/degradation 
when at the highly acidic and protease-rich environment of the human gastrointestinal tract (GIT). Additionally, the therapeutic effects of these macromolecules are limited by their poor stability, low bioavailability, and short half-lives [3,5]. Thus, the micro- or nanoencapsulation of bioactive peptides is often performed to improve their physical stability, biological function, and storage stability but also bioavailability [8]. Several types of colloidal particles have been shown to be capable of encapsulating and improving the bioactivity of proteins.

In the last decades, several proteins and peptides showed therapeutic properties, such as providing health-promoting benefits to the immune, cardiovascular, nervous, and gastrointestinal systems [9-11]. $\alpha$-casozepine is a peptide obtained from the hydrolysis of whey protein that presents anxiolytic activity, exerting benzodiazepine-like activity [12].

In the present study, polymeric microparticles based on a natural polymer (chitosan) were prepared to encapsulate and improve the effectiveness of a relaxing peptide (benzodiazepine-like properties). The excellent physicochemical properties of chitosan and its biological activities make chitosan microparticles a promising system to be used as active ingredient carriers [13-16]. The incorporation of chitosan microparticles into the guar-gum films may increase the bioavailability of the carried bioactive peptide. Therefore, the main objective of the present study is to prepare an oral film incorporating chitosan microparticles to control the release of a relaxing peptide, being a more convenient and effective alternative to improve health and wellbeing.

\section{Materials and Methods}

\subsection{Materials}

The relaxing peptide $\alpha$-casozepine (YLGYLEQLLR peptide sequence) was purchased from GenScript (Piscataway, USA). Guar gum, ethyl acetate, D-sorbitol (assay purity $\geq 98 \%$ ), chitosan low molecular weight (50,000-190,000 Da, 75-85\% of deacetylation), pentasodium tripolyphosphate (TPP), $\alpha$-amylase, pepsin, bovine bile salts, pancreatin, and phosphatebuffered saline tablets (PBS) were purchased from Sigma-Aldrich (Steinheim, Germany). Citric acid monohydrate, potassium phosphate monobasic anhydrous, and sodium phosphate dibasic were obtained from Merck (Darmstadt, Germany). Sodium chloride was purchased from Panreac (Barcelona, Spain). Glacial acetic acid, sodium hydroxide, and all other chemicals were analytical grade, purchased from Sinopharm Chemical Reagent Co., Ltd., Shanghai, China. Ultrapure water was used to prepare all formulations.

TR146, Caco-2, and HT29-MTX cells lines were purchased from Sigma-Aldrich (Stenheim, Germany). Fetal bovine serum (FBS), HAMS-F12 and DMEM culture medium, and Pen-Strep (10,000 U Penicillin, 10,000 U Streptomycin) were purchased from Lonza ${ }^{\circledR}$ (Verviers, Belgium). TrypLETM express was purchased from Gibco ${ }^{\circledR}$ (Taastrup, Denmark). Thiazolyl Blue Tetrazolium Bromide (MTT) was purchased from VWR (Solon, OH, USA). Dimethyl sulphoxide (DMSO) 99.7\% was purchased from Fisher BioreagentsTM (Pennsylvania, EUA). Ninety-six-well culture plates were purchased from Thermo Scientific (Hvidovre, Denmark). Twelve-well culture plate Transwells ${ }^{\circledR}$ inserts $(0.4 \mu \mathrm{m}$ pore size and $1.12 \mathrm{~cm}^{2}$ of culture area) were purchased from Sigma-Aldrich (Steinheim, Germany).

\subsection{Preparation and Characterization of Chitosan Microparticles Loaded with Relaxing Peptide}

Chitosan microparticles (CH MPs) were prepared by the ionic gelation method of chitosan using TPP as a counterion [17], in which the positively charged amino groups of chitosan interact with the negatively charged TPP. Briefly, chitosan solutions were prepared by dissolving $40 \mathrm{mg}$ of chitosan in $2 \mathrm{~mL}$ of deionized water containing $1 \%(\mathrm{v} / \mathrm{v})$ acetic acid [18]. After, the peptide $(125 \mu \mathrm{g} / \mathrm{mL})$ was dissolved in the chitosan solution. Finally, $1.5 \mathrm{mg}$ of TPP as a cross-linker was added and was left under stirring at $1000 \mathrm{rpm}$ for $90 \mathrm{~min}$. Microparticles were formed spontaneously upon incorporation of TPP to chitosan solution. 


\subsubsection{Particle Size Distribution and Surface Charge}

Particle size distribution (mean diameter and polydispersity index) and zeta potential were both determined by dynamic light scattering and electrophoretic light scattering, respectively, using a Malvern Zetasizer Nano ZS instrument (Malvern Instruments Ltd., Worcestershire, UK). The analysis was performed at room temperature using samples appropriately diluted in $0.1 \mathrm{M} \mathrm{NaCl}$ saline solution. For each sample, the mean size of three determinations was calculated. Values reported are the mean \pm standard deviation of at least three different batches of nanoparticles.

\subsubsection{Association Efficiency and Drug Loading}

The peptide association efficiency into CH MPs was determined upon separation of MPs from the aqueous preparation medium containing the non-associated protein by centrifugation $\left(15,000 \mathrm{~g}, 45 \mathrm{~min}, 15^{\circ} \mathrm{C}\right)$ according to Equation (1),

$$
\frac{W t c-W s c}{W t c} \times 100
$$

where Wtc stands for total weight of relaxing peptide added to the formulations of chitosan microparticles, and Wsc stands for peptide collected from the supernatant after centrifugation.

Peptide Quantification

The amount of free peptide was determined in the supernatant by a LC-ESI-QqTOFHRMS method. The LC-ESI-UHR-QqTOF-MS analysis was performed on a UltiMate 3000 Dionex UHPLC (Thermo Scientific), coupled to a Ultra-High Resolution Qq-TimeOf-Flight mass spectrometer with 50,000 Full-Sensitivity Resolution (Impact II, Bruker Daltonics, Bremen, Germany). Separation of metabolites was performed using an Acclaim RSLC 120 C18 column $(100 \mathrm{~mm} \times 2.1 \mathrm{~mm}, 2.2 \mathrm{um})$ (Dionex) a $60^{\circ} \mathrm{C}$. Mobile phases were $0.1 \%$ aqueous formic acid (solvent $\mathrm{A}$ ) and acetonitrile with $0.1 \%$ formic acid (solvent $\mathrm{B}$ ). The gradient started with $5 \%$ and increased to $95 \%$ in $7 \mathrm{~min}$, which was kept constant for $2 \mathrm{~min}$ and returned to $5 \% \mathrm{~B}$ in $1 \mathrm{~min}$ and maintained at $5 \% \mathrm{~B}$ for an additional $5 \mathrm{~min}$ at a flow rate of $0.25 \mathrm{~mL} / \mathrm{min}$. The injection volume was $3 \mu \mathrm{L}$. Parameters for MS analysis were set using positive ionization mode with spectra acquired over a mass range $m / z 150$ to 2500 . The parameters were as follows: capillary voltage, $4.5 \mathrm{kV}$; drying gas temperature, $180^{\circ} \mathrm{C}$, drying gas flow, $8.0 \mathrm{~L} / \mathrm{min}$; nebulizing gas pressure, 1.6 bar, collision $\mathrm{RF}, 1500 \mathrm{Vpp}$; transfer time, 100 us, and prepulse storage, 10 us. Post-acquisition internal mass calibration used ESI-L Low/concentration tuning mix solution delivered by a syringe pump at the start of each chromatographic analysis.

\subsection{Preparation Guar-Gum Films with Relaxing Peptide Loaded into Chitosan Microparticles}

Guar-gum films were prepared by the solvent casting technique [19]. Briefly, $54 \mathrm{mg}$ of sorbitol, $40 \mathrm{mg}$ of guar gum, and $7.6 \mathrm{mg}$ of citric acid were added to $2 \mathrm{~mL}$ of distilled water; then, chitosan microparticles were added and stirred until complete dispersion.

\subsection{Fourier-Transform Infrared Spectroscopy (FTIR)}

Fourier-transform infrared spectra was obtained for guar-gum films, chitosan microparticles, guar-gum films, and chitosan microparticles to assess eventual chemical interactions with relaxing peptide. The analysis was conducted in a FTIR spectrometer, model ABB MB3000 (ABB, Bürozeiten, Switzerland), equipped with a deuterated triglycine sulphate detector, and using a MIRacleTM single reflection horizontal attenuated total reflectance accessory (PIKE Technologies, Fitchburg, MA, USA) with a diamond/Se crystal plate. The spectra were acquired with 256 scans and $4 \mathrm{~cm}^{-1}$ resolution, in the region of $4000-500 \mathrm{~cm}^{-1}$. 


\subsection{In Vitro Release Assay}

In vitro release assays for buccal mucosa were performed to compare the release profile of relaxing peptides from guar-gum films, chitosan microparticles, and chitosan microparticles incorporated into guar-gum films.

The in vitro release of the relaxing peptide was monitored by dialysis membrane (2000 Da) in PBS solution at $37^{\circ} \mathrm{C}$. The samples were suspended in $3 \mathrm{~mL}$ of artificial saliva solution ( $\mathrm{pH}$ 6.8) and placed in a dialysis membrane, clumped and dipped into $30 \mathrm{~mL}$ of PBS solution (release media) and kept at $37^{\circ} \mathrm{C}$ with continuous mixing (100 rpm). Aliquots of $1 \mathrm{~mL}$ were withdrawn from release media at 15, 30, 60, 120, 180, and $240 \mathrm{~min}$. Withdrawn volume was immediately replaced with $1 \mathrm{~mL}$ of PBS to maintain sink conditions. The concentration of relaxing peptide was determined by the LC-ESI-QqTOF-HRMS method.

\subsection{Cell-Based In Vitro Assays}

\subsubsection{Cell Culture}

The TR146 cells, obtained from a human buccal carcinoma, were selected as an in vitro model of the human buccal epithelium. After TR146 cell line cultured forms a stratified epithelium similar to the buccal epithelium [20-22]. The TR146 cells were grown in HAMS F-12 Medium with supplements of 10\% (v/v) fetal bovine serum (FBS), and $1 \%(v / v)$ antibiotic/antimitotic mixture (final concentration of $100 \mathrm{U} / \mathrm{mL}$ Penicillin and $100 \mathrm{U} / \mathrm{mL}$ Streptomycin). Culture conditions were maintained at $37^{\circ} \mathrm{C}$ and $5 \% \mathrm{CO}_{2}$ and $95 \%$ relative humidity (BB 16 gas incubator, Heraeus Instruments $\mathrm{GmbH}$, Hanau, Germany). Subcultivation was performed at approximately $80 \%$ confluence with $0.25 \%$ trypsin-EDTA to detach the cells from the flasks and seeded in 96-well culture plates (with a final density of $2 \times 10^{5} \mathrm{cells} / \mathrm{cm}^{2}$ ) and in 12-well culture plates in Transwells ${ }^{\circledR}$ inserts (with a final density of $1 \times 10^{5}$ cells $/ \mathrm{cm}^{2}$ ). The culture medium was replaced every other day.

Caco-2 and HT29-MTX cell lines were used as in vitro model to assess the intestinal permeation of the relaxing peptide [18]. HT29-MTX cell line was used in co-culture with and Caco-2 cell line to mimic the intestinal epithelial conditions. Cells line were grown separately, in Dulbecco's Modified Eagle Medium (DMEM) with supplements of $10 \%(v / v)$ fetal bovine serum (FBS), $1 \%(v / v)$ L-glutamine, $1 \%(v / v)$ antibiotic/antimitotic mixture (final concentration of $100 \mathrm{U} / \mathrm{mL}$ Penicillin and $100 \mathrm{U} / \mathrm{mL}$ Streptomycin), and $1 \%(v / v)$ of non-essential amino acids. Culture conditions were maintained at $37^{\circ} \mathrm{C}$ and $5 \% \mathrm{CO}_{2}$ and $95 \%$ relative humidity. Sub-cultivation was performed at approximately $80 \%$ confluence with $0.25 \%$ trypsin-EDTA; to detach the cells from the flasks and co-culture, seeding in Transwells ${ }^{\circledR}$ was performed at 9:1 ratio of Caco-2 and HT29 with a final density of $1 \times 10^{5}$ cells $/ \mathrm{cm}^{2}$ in each insert. Cells were maintained in an incubator (BB 16 gas incubator, Heraeus Instruments $\mathrm{GmbH}$ ) at $37^{\circ} \mathrm{C}$ and $5 \% \mathrm{CO}_{2}$ and $95 \%$ relative humidity for 21 days with medium $(0.5 \mathrm{~mL}$ in the apical side and $1.5 \mathrm{~mL}$ in the basolateral side) changed every other day.

\subsubsection{Cell Viability Studies MTT Assay}

Cell viability of TR146 cell line, after $24 \mathrm{~h}$ treatment with chitosan microparticles, guargum films, with or without peptide, were measured using the methylthiazolydiphenyltetrazolium bromide conversation (MTT) assay [18].

Cells were seeded in 96-well plates at $2 \times 10^{5} /$ well in $300 \mu \mathrm{L}$ culture medium and incubated for $24 \mathrm{~h}$ at $37{ }^{\circ} \mathrm{C}$ in $5 \% \mathrm{CO}_{2}$ environment. The medium was then changed, and the cells were treated with test samples (peptide, chitosan microparticles, chitosan microparticles with peptide; guar-gum films; guar-gum films with peptide; guar-gum films with chitosan microparticles with peptide or free) for $24 \mathrm{~h}$. Each treatment was tested in eight individual wells. After $24 \mathrm{~h}$, the supernatant was removed, and $200 \mu \mathrm{L}$ of MTT solution $(5 \mathrm{mg} / \mathrm{mL}$ in DMEM) was added to each well of 96-well plates and then incubated for $4 \mathrm{~h}$ at $37^{\circ} \mathrm{C}$ to allow the formation of formazan crystal. The medium was then removed, and the blue formazan was eluted from cells by $150 \mu \mathrm{L}$ of DMSO. The negative control 
used was also DMSO. The plates were shaken on an orbital shaker to solubilize the crystals of formazan. The dark blue crystals were aspirated to another new 96-well microplate, and the optical density was measured directly in the microplate reader at 570 and $630 \mathrm{~nm}$, read on a FLUOstar OPTIMA microplate reader (United Kingdom). All samples were tested for $\mathrm{n}=5$ experiments with comparable results.

The cell viability of the tested delivery systems was calculated from the average optical density $(O D)$ values, according to Equation (2).

$$
\text { Cell viability }(\%)=\frac{\text { OD value of specimen suspension }}{\text { OD value of negative control suspension }} \times 100
$$

\section{LDH Assay}

LDH assay measures the release of the intracellular enzyme LDH upon damage of the plasma membrane, and an increase in LDH release could be an index of cell damage. For measuring LDH activity, a colorimetric method was used. This method converted lactate to pyruvate in the presence of LDH with parallel reduction in NAD.

Caco-2 cell lines were seeded in a 96-well plate at $2 \times 10^{5} /$ well and incubated for $24 \mathrm{~h}$ at $37^{\circ} \mathrm{C}$ in $5 \% \mathrm{CO}_{2}$ environment. After $24 \mathrm{~h}$, test solution and controls (DMEM and DMSO) were added in triplicate to the cell culture.

Cells were incubated with medium at $37^{\circ} \mathrm{C}$ for $24 \mathrm{~h}$. After this time, cells were washed twice with PBS, and the activity of LDH in the medium was determined using a commercially available kit from Sigma Diagnostics (LDL50). The absorbance was measured at $490 \mathrm{~nm}$ with background subtraction at $690 \mathrm{~nm}$.

\subsubsection{Permeability Assay}

The permeability experiments were assessed using 12-well culture plates with Transwell inserts. TR146 cells were seeded into the inserts to mimic buccal mucosa epithelium, and Caco-2/HT29-MTX co-culture was used to mimic duodenum conditions. After 21 days, the medium was removed every two days. Guar-gum films, chitosan microparticles, guargum film with chitosan microparticles, and free relaxing peptide were tested at $50 \mu \mathrm{g} / \mathrm{mL}$. The substances were applied to the apical side of the cell layers, and the medium was replaced in the basolateral side (1.5 mL of PBS) and in the apical side ( $0.5 \mathrm{~mL}$ of PBS). Samples $(1 \mathrm{~mL})$ were withdrawn from the basolateral side at $0,15,30,60,120,180$, and $240 \mathrm{~min}$. The volume was immediately replaced with fresh PBS. The Transwell culture plates were incubated at $37^{\circ} \mathrm{C}$ in the atmosphere of $5 \% \mathrm{CO}_{2} / 95 \%$ air for maintaining cell viability during permeation studies. The concentration of relaxing peptide was determined by the LC-ESI-QqTOF-HRMS method.

The apparent permeability coefficient (Papp) was calculated from the measurement of the flow rate of relaxing peptide from the donor to the acceptor chambers, according to Equation (3).

$$
\operatorname{app}(c m . s-1)=\frac{d Q}{d t \times A \times C 0}
$$

where $d Q$ is the total amount of permeated relaxing peptide $(\mu \mathrm{g}), \mathrm{A}$ is the diffusion area $\left(\mathrm{cm}^{2}\right), C 0$ is the initial concentration in the donor compartment $(\mu \mathrm{g} / \mathrm{mL})$, and $\mathrm{dt}$ is the time of experiment (s). The coefficient $d Q / d t$ represents the flux of the test compound across the cell layers.

\subsubsection{TEER Measurements}

The culture of TR146 and the co-culture of Caco-2/HT29-MTX were used in permeability assays after 21 days of culture when they were expected to complete their morphological and functional differentiation [23]. The integrity of TR146 monolayer and Caco-2/HT29MTX co-culture were checked by transepithelial electrical resistance (TEER). The TEER was measured across cells growing and after every sample collection when the permeability assay was performed, to assess the cell growth rate and cell viability after contacting 
with tested formulations, using an epithelial voltmeter (Milicell ${ }^{\circledR}$ ERS-2 Voltmeter, Merck, Germany) to evaluate the integrity of the tight junctions (Equation (4)).

$$
\operatorname{TEER}(\Omega . \mathrm{cm}-2)=[\text { TEER }- \text { TEER background }] \times \text { Area }(\mathrm{cm} 2)
$$

where TEER $(\Omega)$ is the electrical resistance across the monolayer directly read from the epithelial voltmeter, TEER background $(\Omega)$ is that of the insert only (without cells), and the area is the surface area of the insert.

\subsection{Stability Assay}

Formulations (film and microparticles with and without peptide) were prepared and stability was assessed according to the quality guidelines Q1A established by the International Conference of Harmonization. Quality guidelines define the accelerated degradation conditions as $40 \pm 2{ }^{\circ} \mathrm{C} / 75 \pm 5 \%$ relative humidity (conditioned chamber Climacell from MMM Medcenter Einrichtungen GmbH, Planegg, Germany). Stability tests compared the chemical integrity characteristics every three and six months of storage. The formulations were also analyzed regarding humidity using an A\&D MX-50 moisture analyzer from A\&D Company Ltd. (Tokyo, Japan).

\subsection{Statistical Analysis}

A one-way analysis of variance (ANOVA) was used to evaluate experimental group comparison. Differences were considered to be statistically significant when the P-values were less than 0.05 . Results are shown as mean \pm standard deviation.

All statistical analysis was performed using SPSS ${ }^{\circledR}$ for Windows version 22 (IBM SPSS, Chicago, IL, USA).

Experimental values were obtained from three samples selected from three new batches for chitosan microparticles (mean \pm standard deviation).

\section{Results}

\subsection{Characterization of Peptide-Loaded Chitosan Microparticles}

Relaxing peptide-loaded chitosan microparticles were prepared by ionic gelation method, and parameters such as particle size, zeta potential, polidispersion index (PDI), association efficiency (AE), and loading capacity were analyzed. The peptide-loaded $\mathrm{CH}$ MPs average size was $1.81 \pm 0.802 \mu \mathrm{m}$, and the zeta potential was $43.5 \pm 9.09 \mathrm{mV}$ (Table 1). The results showed that peptide loading had no observable effect on the physical features of MPs (Table 1).

Table 1. Characteristics of unloaded CH MPs and relaxing peptide-loaded CH MPs (CH MPs + Peptide) $($ mean $\pm \mathrm{sd}(\mathrm{n}=3))$.

\begin{tabular}{ccccc}
\hline & Size $(\mu \mathrm{m})$ & Polidispersion Index & Zeta Potential (mV) & Association Efficiency $(\%)$ \\
\hline CH MPs & $1.16 \pm 0.821$ & $0.926 \pm 0.119$ & $46.5 \pm 12.2$ & - \\
$\begin{array}{c}\text { Relaxing peptide-loaded } \\
\text { CH MPs }\end{array}$ & $1.81 \pm 0.802$ & $0.890 \pm 0.102$ & $43.5 \pm 9.09$ & $86.1 \pm 3.29$ \\
\hline
\end{tabular}

The peptide-loaded CH MPs showed an encapsulation efficiency of about $86 \%$. The peptide loading in $\% w / w$ in chitosan microparticles was $0.63 \%$ and in guar-gum films with chitosan microparticles was $0.18 \%$.

\subsection{Fourier-Transform Infrared Spectroscopy (FTIR) Analysis}

FTIR analysis is proposed to investigate the interaction between substances. In this study relaxing peptide, peptide-loaded chitosan microparticles, peptide-loaded guar-gum films, and peptide-loaded chitosan microparticles into guar-gum films were analyzed through the FTIR spectra to understand the chemical structure stability (Figure 1). The characteristic band of the relaxing peptide could be seen in the fingerprint region between $1100 \mathrm{~cm}^{-1}$ and $1250 \mathrm{~cm}^{-1}$ (C-C-O and C-OH bonds), $1490 \mathrm{~cm}^{-1}$ and $1580 \mathrm{~cm}^{-1}$ 
(amide II band), and $1580 \mathrm{~cm}^{-1}$ and $1740 \mathrm{~cm}^{-1}$ ( $\mathrm{C}=\mathrm{O}$ stretching vibrations and of C-N stretching) [24].

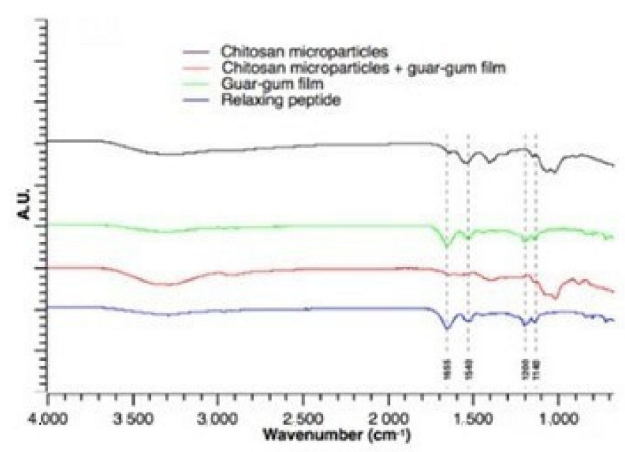

Figure 1. FTIR spectra of free peptide (relaxing peptide) (-) and peptide-loaded chitosan microparticles (-), guar-gum films (-), and chitosan microparticles into guar-gum films (-).

FTIR analysis did not indicate the formation of new covalent bonds between relaxing peptide and chitosan microparticles, guar-gum films, and guar-gum films with chitosan microparticles that could potentially modify peptide release profile [25] (Figure 1).

\subsection{In Vitro Peptide Release}

Relaxing peptide release behavior from chitosan microparticles loading into guar-gum films was evaluated at $\mathrm{pH} 6.8$ (associated with the ionic $\mathrm{H}+$ concentrations of the buccal mucosa) and pH 7.4 (blood circulation), respectively, at a temperature of $37^{\circ} \mathrm{C}$. The results of relaxing peptide release from microspheres in different conditions are shown in Figure 2.

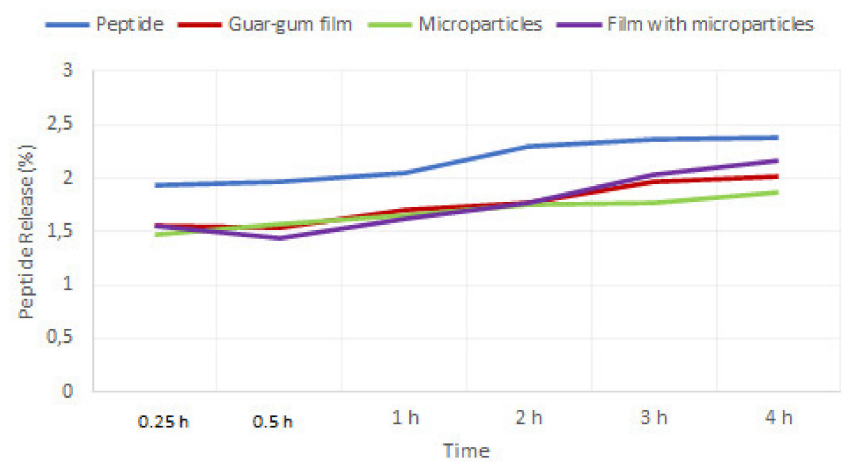

Figure 2. Release profiles of relaxing peptide in different conditions (free relaxing peptide, guar-gum film with peptide, chitosan microparticles with peptide, peptide-loaded chitosan microparticles in guar-gum film) in human physiological conditions.

The peptide release profile from guar-gum films and chitosan microparticles and chitosan microparticles into guar-gum films were very similar along 240 min of study, also indicating that both formulations offered a slower release of carried peptide when compared to the free relaxing peptide. The peptide release from guar-gum films and guar-gum films increased after $30 \mathrm{~min}$, probably because the film disintegrated, leading to a gradual dissolution of the carrier peptide.

No significant differences were found between the dissolution profile of guar-gum films, chitosan microparticles, and chitosan microparticles loaded into guar-gum films. 


\subsection{In Vitro Assays}

\subsubsection{Cell Viability Assay}

Cytotoxicity is an important factor to evaluate the viability of cells by detecting the toxicity of material release. Among the biocompatibility assay, cytotoxicity is a favorite as it is simple, fast, and highly sensitive. The cytotoxic effect of peptide-loaded chitosan microparticles incorporated into guar-gum films was evaluated in TR146 cells by using the MTT assay. The MTT reagent is composed of yellow tetrazolium salt that turns into purple formazan crystals when cells are viable. Figure 3 shows the cellular viability obtained with the MTT assay of TR146 cells, which were put in contact with guar-gum films with peptideloaded chitosan microparticles for $24 \mathrm{~h}$. The results showed that all experimental conditions tested (i.e., chitosan microparticles, peptide-loaded chitosan microparticles, guar-gum films, peptide-loaded guar-gum films, guar-gum films with chitosan microparticles, and guar-gum films with peptide-loaded chitosan microparticles) assured high cell viability (75-99\%), indicating that the guar-gum films with peptide-loaded chitosan microparticles are biocompatible. These results were in a good correlation with those from the LDH assay.

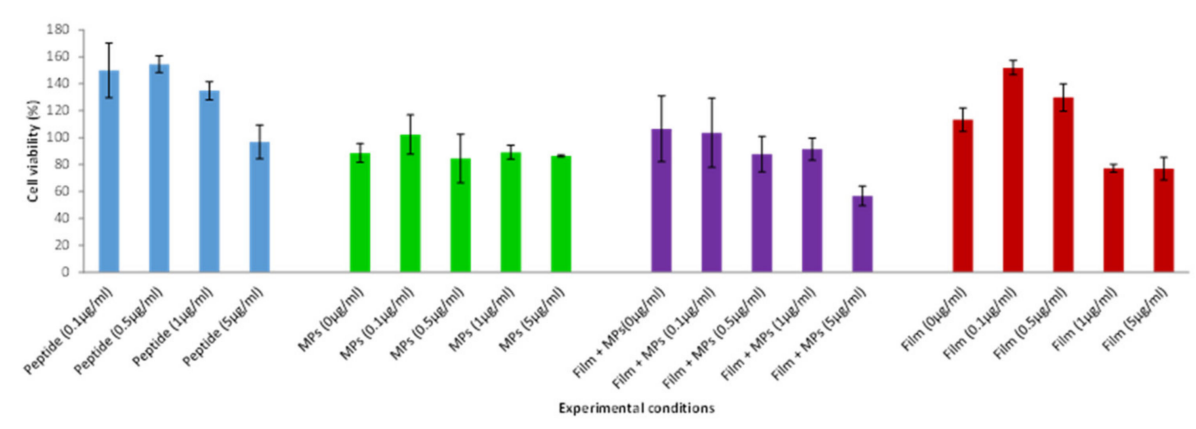

Figure 3. Cell viability ( $\%$, mean $\pm \mathrm{SD})$ when in contact with relaxing peptide, chitosan microparticles, guar-gum films, and chitosan microparticles loaded into guar-gum films with and without peptide, determined by the MTT assay after $24 \mathrm{~h}$ of $\operatorname{contact}(n=5)$.

\subsubsection{Permeability Assay}

Changes in buccal and intestinal permeability were assessed by measuring relaxing peptide transport across TR146 and Caco-2/HT29 (co-culture) cell layers, and epithelial tight junction integrity was assessed by measuring transepithelial electrical resistance (TEER).

The TEER was monitored throughout the permeability study as an indicator of the integrity of the TR146 cell culture and for Caco-2/HT29-MTX co-culture (cells layer with TEER above $150 \Omega . \mathrm{cm}^{2}$ and $200 \Omega . \mathrm{cm}^{2}$, respectively) [26,27]. The permeability of the relaxing peptide across TR146 monolayer and Caco-2/HT29 co-culture is outlined in Figure 4 .

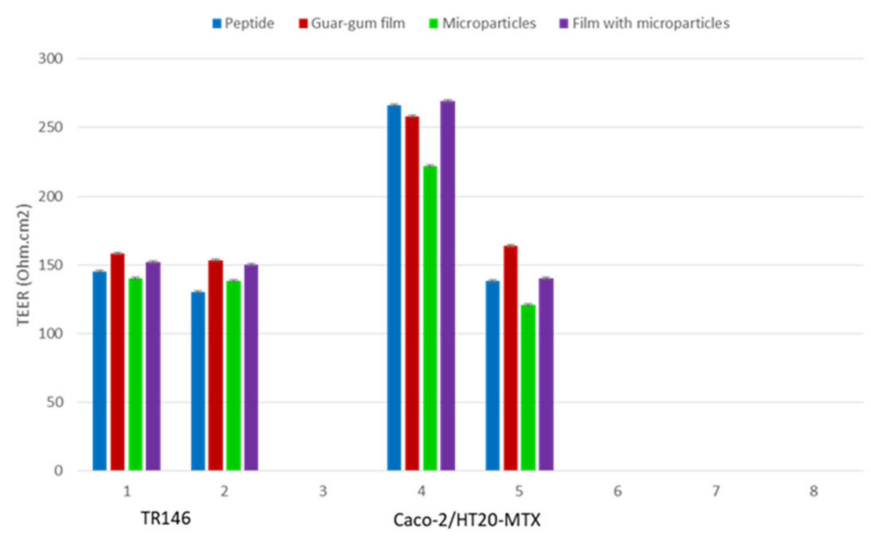

Figure 4. TEER cell monolayer TR146 and co-culture Caco-2/HT29 measurement. 
The results showed the efficacy of the buccal delivery systems enhancing the permeation of carried peptides. The developed formulations guaranteed higher peptide permeation across buccal mucosa when compared to relaxing peptide alone (Figure 5).

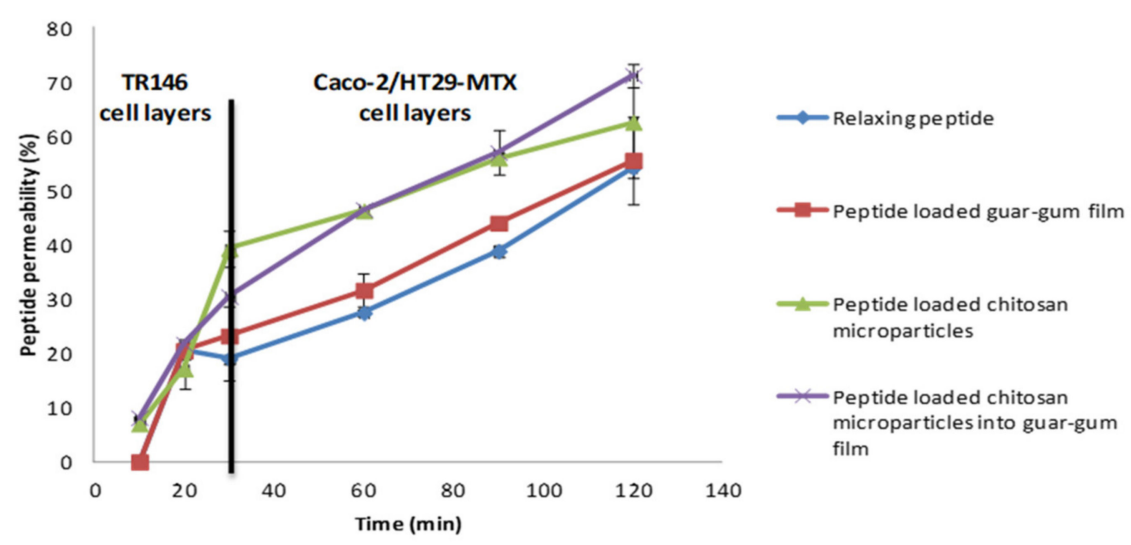

Figure 5. Cumulative relaxing peptide transport measurements across TR146 and Caco-2/HT29-MTX co-culture model in Transwell membranes expressed as peptide permeability (\%, mean $\pm \mathrm{SD})$.

The relaxing peptide permeability coefficient (Papp) was calculated for all samples (Table 2). The apparent permeability of relaxing peptide carried by chitosan microparticles into guar-gum films was significantly higher $(p<0.05)$ across TR146 cell layers, when compared with remaining formulations and control solution, as outlined in Table 2 . The cumulative permeability of relaxing peptide across Caco-2/HT29-MTX was also observed for peptide-loaded chitosan microparticles into guar-gum films. The results showed the uptake of chitosan microparticles by Caco- 2 intestinal cells can explain the extensive permeation of the peptide carried by peptide-loaded chitosan microparticles into guar-gum films across Caco-2/HT29-MTX co-culture.

Table 2. Apparent permeability coefficient of relaxing peptide across TR146 and Caco-2/HT29 co-culture model.

\begin{tabular}{ccc}
\hline Formulation & Papp (cm/s) across TR146 Cell Layers & Papp (cm/s) across Caco-2/HT29 Cell Layers \\
\hline Peptide & $8.79 \times 10^{-5} \pm 1.88 \times 10^{-5}$ & $1.24 \times 10^{-4} \pm 8.96 \times 10^{-6}$ \\
Guar-gum films & $1.07 \times 10^{-4} \pm 2.47 \times 10^{-5}$ & $1.11 \times 10^{-4} \pm 4.83 \times 10^{-5}$ \\
Chitosan microparticles & $1.49 \times 10^{-4} \pm 1.77 \times 10^{-5}$ & $4.26 \times 10^{-5} \pm 2.96 \times 10^{-5}$ \\
$\begin{array}{c}\text { Guar-gum films with } \\
\text { chitosan microparticles }\end{array}$ & $1.03 \times 10^{-4} \pm 3.38 \times 10^{-5}$ & $1.14 \times 10^{-4} \pm 9.73 \times 10^{-6}$ \\
\hline
\end{tabular}

\subsection{Storage Stability}

The humidity rates of peptide chitosan microparticles loaded into guar-gum films were determined over six months. During the first 3 months, the moisture uptake rates increased $(8.9 \%)$ and, after this time, had a little decrease (8.2\%). These results suggested that the microspheres could absorb an amount of moisture at $40{ }^{\circ} \mathrm{C}$ and a relative humidity of $75 \%$.

\section{Discussion}

Relaxing peptide-loaded chitosan microparticles were prepared, characterized, and evaluated. The evaluation of the physical-chemical and biological properties are important, since they are correlated with therapeutic potential effects. These microparticles exhibited good stability, and no aggregation occurred when in suspension. The positive value of zeta potential was probably due to the positive charge of chitosan and the high positive zeta potential indicated that the electrostatic repulsion between particles prevented aggregation and increased their stability. So, these results showed that peptide loading had no observable effect on the physical features of MPs. The relaxing peptide was successfully 
entrapped into the CH MPs with high loading efficiencies, indicating a good potential of $\mathrm{CH}$ MPs as a delivery system of these peptides. The relaxing peptide $\alpha$-casozepine has a lower isoelectric point ( $\mathrm{pH}$ 6.56) and, therefore, a higher negative surface charge under particle formulation conditions, facilitating increased electrostatic interactions with polycationic chitosan. Association efficiencies and particles mean sizes are important indexes of the quality of the delivery systems. The process of encapsulation should generate a high yield of particles, and the levels of loading for these peptide formulations are appropriate for their potential therapeutic applications. The small sizes could enhance the absorption of buccal cells [28-31]. In other studies, chitosan is widely described as bioavailable, with excellent physicochemical properties, as well as a mucoadhesive polymer that is able to increase cellular permeability and improve the bioavailability of orally administered protein drugs [28-30,32-34]. The high AE values of loaded CH MPS are corroborated by Pan and collaborators (2002) when they have prepared insulin-loaded chitosan nanoparticles with values of insulin association up to $80 \%$, as well as Song and collaborators and other authors [14,35-38].

An FTIR analysis is proposed to investigate the interaction between substances. The regions of both amide I and amide II of relaxing peptide and relaxing peptide-loaded formulations present an overlapping, which is an indicator that there was no chemical structure modification of carried peptide during incorporation or production of the new delivery systems [4]. FTIR analysis did not indicate the formation of new covalent bonds between relaxing peptide and chitosan microparticles, guar-gum films, and guar-gum films with chitosan microparticles that could potentially modify the peptide release profile. Through the in vitro peptide release assays, it was verified that the peptide release profile from guar-gum films and chitosan microparticles and chitosan microparticles into guargum films were very similar, indicating that both formulations offered a slower release of carried peptide when compared to the free relaxing peptide.

Regarding the biological characterization, this study showed that chitosan microparticles, peptide-loaded chitosan microparticles, guar-gum films, peptide-loaded guar-gum films, guar-gum films with chitosan microparticles, and guar-gum films with peptideloaded chitosan microparticles showed biocompatible properties.

Cell permeability of relaxing peptide into the tested systems (chitosan microparticles, guar-gum films, and peptide-loaded chitosan microparticles into guar-gum films) was compared with the free peptide. Oral delivery systems showed a faster permeability than the free peptide. So, results obtained are promising regarding the overall bioavailability enhancement of carried peptide, showing that the guar-gum film with chitosan microparticles with relaxing peptide was an efficient system promoting relaxing peptide permeability, due to the increased permeability across absorptive epithelia and regarding the protection of the peptide along the gastrointestinal tract.

For this purpose, the use of chitosan as one of the most effective polymers for improving the transmucosal absorption of molecules (the ability to open intercellular tight junctions), its mucoadhesive property, and permeability enhancement were shown in this study and in others [39-43]. Similar studies with other delivery systems with chitosan composition also showed a controlled release of protein/peptide [40,43].

Chitosan is known to increase the effectiveness of the permeation of protein across the mucosal epithelia, and the dual functionalization with chitosan and peptide will allow a longer residence time in the intestine; also, effective penetration through tight junction was reported by Lee and collaborators [41]. Therefore, the success of this delivery system accrues the oral films' composition, with chitosan and other polymers, that present mucoadhesive and permeation enhancing nature properties.

When analyzing the storage stability, the results showed that the films should be kept away from humidity when stored, so an adequate packaging system must be envisaged. The moisture content in relaxing peptide-loaded chitosan microparticles into guar-gum films increased over time under accelerated degradation conditions. Therefore, the moisture content increase can indicate that stability may decrease over time due to higher water 
activity, which may lead to formulation stability problems and the potential growth of microorganisms. Additionally, the high moisture content may promote the migration of bioactive molecules within the delivery system, leading to a heterogeneous formulation and compromising the pharmacokinetic function of the formulation $[44,45]$.

\section{Conclusions}

Oral films have gained relevance in delivery systems, due to good physical-chemical and biological properties and advantages in the release and permeation of drugs and bioactive molecules across the buccal and intestinal mucosa. In this study, an oral delivery system based on the combination guar-gum films and chitosan microparticles was developed, joining the advantages of the orodispersible film with that gained from microcarriers as oral delivery systems for a peptide with relaxing function (benzodiazepine-like). The innovative concept to incorporate microparticles and oral films resulted in a higher synergism and offer a higher mucoadhesion along the gastrointestinal tract when compared to the remaining formulations. This combination represents an adequate delivery system, the incorporation of peptide chitosan microparticles into biocompatible guar-gum oral films did not compromise cell viability and offered a faster permeability across the TR146 monolayer and Caco-2/HT29 co-culture and effectiveness regarding the enhancement of both buccal and intestinal permeation of carried relaxing peptide when compared with a free peptide. The results indicate that there is a synergistic effect between chitosan microparticles and guar-gum films that promotes an intimate contact with buccal epithelia, leading to more extensive absorption over time. Hence, peptide-loaded chitosan microparticles into guar-gum oral films (with components classified as food and given the status Generally Recognized as Safe by the Food and Drug Administration agency) might be a promising carrier for buccal administration, to improve therapeutical relaxing functions into the body by peptide (relaxing peptide).

Author Contributions: Conceptualization and design of the study, data collection, writing-original draft preparation, P.B.; formal analysis, investigation, writing, P.M.C.; writing-review and editing, A.R.M., B.S., M.P.; supervision, project administration, M.P. All authors have read and agreed to the published version of the manuscript.

Funding: This research was funded by the project NORTE-01-0145-FEDER-000012, supported by Norte Portugal Regional Operational Programme (NORTE 2020), under the PORTUGAL 2020 Partnership Agreement, through the European Regional Development Fund (ERDF); Pedro M. Castro, PhD grant (NORTE-08-5369-FSE-000007); National funds from FCT through project PTDC/BBBNAN/3249/2014.

Conflicts of Interest: The authors declare no conflict of interest.

\section{References}

1. Castro, P.M.; Fonte, P.; Sousa, F.; Madureira, A.R.; Sarmento, B.; Pintado, M.E. Oral films as breakthrough tools for oral delivery of proteins / peptides. J. Control. Release 2015, 211, 63-73. [CrossRef]

2. Mazzarino, L.; Borsali, R.; Lemos-Senna, E. Mucoadhesive films containing chitosan-coated nanoparticles: A new strategy for buccal curcumin release. J. Pharm. Sci. 2014, 103, 3764-3771. [CrossRef] [PubMed]

3. Batista, P.; Castro, P.M.; Madureira, A.R.; Sarmento, B.; Pintado, M. Recent insights in the use of nanocarriers for the oral delivery of bioactive proteins and peptides. Peptides 2018, 101, 112-123. [CrossRef] [PubMed]

4. Castro, P.M.; Sousa, F.; Magalhães, R.; Ruiz-Henestrosa, V.M.P.; Pilosof, A.M.; Madureira, A.R.; Sarmento, B.; Pintado, M.E. Incorporation of beads into oral films for buccal and oral delivery of bioactive molecules. Carbohydr. Polym. 2018, 194, 411-421. [CrossRef] [PubMed]

5. Giovino, C.; Ayensu, I.; Tetteh, J.; Boateng, J.S. Development and characterisation of chitosan films impregnated with insulin loaded PEG-b-PLA nanoparticles (NPs): A potential approach for buccal delivery of macromolecules. Int. J. Pharm. 2012, 428, 143-151. [CrossRef]

6. Prabaharan, M. Prospective of guar gum and its derivatives as controlled drug delivery systems. Int. J. Biol. Macromol. 2011, 49, 117-124. [CrossRef]

7. Seeli, D.S.; Prabaharan, M.; Thakur, V.; Thakur, M. Guar gum and its derivatives: Versatile materials for controlled drug delivery. In Handbook of Sustainable Polymers; CRC Press: Boca Raton, FL, USA, 2016; pp. 261-287. 
8. McClements, D.J. Encapsulation, protection, and delivery of bioactive proteins and peptides using nanoparticle and microparticle systems: A review. Adv. Colloid Interface Sci. 2018, 253, 1-22. [CrossRef]

9. Fosgerau, K.; Hoffmann, T. Peptide therapeutics: Current status and future directions. Drug Discov. Today 2015, 20, 122-128. [CrossRef]

10. Dullius, A.; Goettert, M.I.; de Souza, C.F.V. Whey protein hydrolysates as a source of bioactive peptides for functional foodsBiotechnological facilitation of industrial scale-up. J. Funct. Foods 2018, 42, 58-74. [CrossRef]

11. Ma, G. Microencapsulation of protein drugs for drug delivery: Strategy, preparation, and applications. J. Control. Release 2014, 193, 324-340. [CrossRef]

12. Yoshikawa, M. Bioactive peptides derived from natural proteins with respect to diversity of their receptors and physiological effects. Peptides 2015, 72, 208-225. [CrossRef]

13. Khan, G.; Yadav, S.K.; Patel, R.R.; Nath, G.; Bansal, M.; Mishra, B. Development and evaluation of biodegradable chitosan films of metronidazole and levofloxacin for the management of periodontitis. AAPS PharmSciTech 2016, 17, 1312-1325. [CrossRef] [PubMed]

14. Rodriguez, L.B.; Avalos, A.; Chiaia, N.; Nadarajah, A. Effect of formulation and process parameters on chitosan microparticles prepared by an emulsion crosslinking technique. AAPS PharmSciTech 2017, 18, 1084-1094. [CrossRef] [PubMed]

15. Effendi, C.M.; Fitriani, D.; Nurmawlidina, M.F. The effect difference of chitosan nanoparticles, chitosan microparticles, and casein phosphopeptide- amorphous calcium phosphate in reducing enamel demineralization. Sci. Dent. J. 2020, 4, 84-87. [CrossRef]

16. Sette-de-Souza, P.H.; de Santana, C.P.; Amaral-Machado, L.; Duarte, M.C.T.; de Medeiros, F.D.; Veras, G.; de Medeiros, A.C.D. Antimicrobial activity of schinopsis brasiliensis engler extract-loaded chitosan microparticles in oral infectious disease. AAPS PharmSciTech 2020, 21, 246. [CrossRef]

17. Calvo, P.; Remunan-Lopez, C.; Vila-Jato, J.L.; Alonso, M. Novel hydrophilic chitosan-polyethylene oxide nanoparticles as protein carriers. J. Appl. Polym. Sci. 1997, 63, 125-132. [CrossRef]

18. Araújo, F.; Shrestha, N.; Shahbazi, M.-A.; Fonte, P.; Mäkilä, E.; Salonen, J.J.; Hirvonen, J.T.; Granja, P.; Santos, H.A.; Sarmento, B. The impact of nanoparticles on the mucosal translocation and transport of GLP-1 across the intestinal epithelium. Biomaterials 2014, 35, 9199-9207. [CrossRef]

19. Castro, P.M.; Fonte, P.; Oliveira, A.; Madureira, A.R.; Sarmento, B.; Pintado, M.E. Optimization of two biopolymer-based oral films for the delivery of bioactive molecules. Mater. Sci. Eng. C 2017, 76, 171-180. [CrossRef]

20. Jacobsen, J.; Pedersen, M.; Rassing, M.R. TR146 cells as a model for human buccal epithelium: II. Optimisation and use of a cellular sensitivity MTS/PMS assay. Int. J. Pharm. 1996, 141, 217-225. [CrossRef]

21. Nielsen, H.M.; Rassing, M.R. TR146 cells grown on filters as a model of human buccal epithelium: IV. Permeability of water, mannitol, testosterone and $\beta$-adrenoceptor antagonists. Comparison to human, monkey and porcine buccal mucosa. Int. J. Pharm. 2000, 194, 155-167. [CrossRef]

22. Portero, A.; Remuñán-López, C.; Nielsen, H.M. The potential of chitosan in enhancing peptide and protein absorption across the TR146 cell culture model-An in vitro model of the buccal epithelium. Pharm. Res. 2002, 19, 169-174. [CrossRef] [PubMed]

23. Guri, A.; Gülseren, I.; Corredig, M. Utilization of solid lipid nanoparticles for enhanced delivery of curcumin in cocultures of HT29-MTX and Caco-2 cells. Food Funct. 2013, 4, 1410-1419. [CrossRef] [PubMed]

24. Nixon, A.E. Therapeutic Peptides: Methods and Protocols; Springer: Berlin/Heidelberg, Germany, 2014.

25. Ferreira-Nunes, R.; Gratieri, T.; Gelfuso, G.M.; Cunha-Filho, M. Mixture design applied in compatibility studies of catechin and lipid compounds. J. Pharm. Biomed. Anal. 2018, 149, 612-617. [CrossRef]

26. Pan, F.; Han, L.; Zhang, Y.; Yu, Y.; Liu, J. Optimization of Caco-2 and HT29 co-culture in vitro cell models for permeability studies. Int. J. Food Sci. Nutr. 2015, 66, 680-685. [CrossRef]

27. Septiadi, D.; Crippa, F.; Moore, T.L.; Rothen-Rutishauser, B.; Petri-Fink, A. Nanoparticle-cell interaction: A cell mechanics perspective. Adv. Mater. 2018, 30, 1704463. [CrossRef]

28. Da Silva, C.F.; Severino, P.; Martins, F.; Santana, M.H.A.; Souto, E.B. Didanosine-loaded chitosan microspheres optimized by surface-response methodology: A modified "Maximum Likelihood Classification" approach formulation for reverse transcriptase inhibitors. Biomed. Pharmacother. 2015, 70, 46-52. [CrossRef]

29. Kumbar, S.G.; Aminabhavi, T.M. Synthesis and characterization of modified chitosan microspheres: Effect of the grafting ratio on the controlled release of nifedipine through microspheres. J. Appl. Polym. Sci. 2003, 89, 2940-2949. [CrossRef]

30. Tao, C.; Huang, J.; Lu, Y.; Zou, H.; He, X.; Chen, Y.; Zhong, Y. Development and characterization of GRGDSPC-modified poly (lactide-co-glycolide acid) porous microspheres incorporated with protein-loaded chitosan microspheres for bone tissue engineering. Colloids Surf. B Biointerfaces 2014, 122, 439-446. [CrossRef]

31. Yu, T.; Zhao, S.; Li, Z.; Wang, Y.; Xu, B.; Fang, D.; Wang, F.; Zhang, Z.; He, L.; Song, X.; et al. Enhanced and extended anti-hypertensive effect of VP5 nanoparticles. Int. J. Mol. Sci. 2016, 17, 1977. [CrossRef] [PubMed]

32. Bowman, K.; Leong, K.W. Chitosan nanoparticles for oral drug and gene delivery. Int. J. Nanomed. 2006, 1, 117. [CrossRef] [PubMed]

33. Dammak, I.; Bittante, A.M.Q.B.; Lourenço, R.V.; do Amaral Sobral, P.J. Properties of gelatin-based films incorporated with chitosan-coated microparticles charged with rutin. Int. J. Biol. Macromol. 2017, 101, 643-652. [CrossRef]

34. Walke, S.; Srivastava, G.; Nikalje, M.; Doshi, J.; Kumar, R.; Ravetkar, S.; Doshi, P. Fabrication of chitosan microspheres using vanillin/TPP dual crosslinkers for protein antigens encapsulation. Carbohydr. Polym. 2015, 128, 188-198. [CrossRef] 
35. Pan, Y.; Li, Y.-J.; Zhao, H.-Y.; Zheng, J.-M.; Xu, H.; Wei, G.; Hao, J.-S.; Cui, F.-D. Bioadhesive polysaccharide in protein delivery system: Chitosan nanoparticles improve the intestinal absorption of insulin in vivo. Int. J. Pharm. 2002, 249, 139-147. [CrossRef]

36. Sarmento, B.; Ribeiro, A.; Veiga, F.; Ferreira, D.; Neufeld, R. Oral bioavailability of insulin contained in polysaccharide nanoparticles. Biomacromolecules 2007, 8, 3054-3060. [CrossRef]

37. Song, L.; Zhi, Z.-L.; Pickup, J.C. Nanolayer encapsulation of insulin-chitosan complexes improves efficiency of oral insulin delivery. Int. J. Nanomed. 2014, 9, 2127.

38. Zhang, H.; Oh, M.; Allen, C.; Kumacheva, E. Monodisperse chitosan nanoparticles for mucosal drug delivery. Biomacromolecules 2004, 5, 2461-2468. [CrossRef] [PubMed]

39. Elgadir, M.A.; Uddin, M.S.; Ferdosh, S.; Adam, A.; Chowdhury, A.J.K.; Sarker, M.Z.I. Impact of chitosan composites and chitosan nanoparticle composites on various drug delivery systems: A review. J. Food Drug Anal. 2015, 23, 619-629. [CrossRef] [PubMed]

40. Jing, Z.-W.; Ma, Z.-W.; Li, C.; Jia, Y.-Y.; Luo, M.; Ma, X.-X.; Zhou, S.-Y.; Zhang, B.-L. Chitosan cross-linked with poly (ethylene glycol) dialdehyde via reductive amination as effective controlled release carriers for oral protein drug delivery. Bioorganic Med. Chem. Lett. 2017, 27, 1003-1006. [CrossRef]

41. Lee, J.H.; Sahu, A.; Choi, W.I.; Lee, J.Y.; Tae, G. ZOT-derived peptide and chitosan functionalized nanocarrier for oral delivery of protein drug. Biomaterials 2016, 103, 160-169. [CrossRef]

42. Moreno, J.A.S.; Panou, D.-A.; Stephansen, K.; Chronakis, I.S.; Boisen, A.; Mendes, A.C.; Nielsen, L.H. Preparation and characterization of an oral vaccine formulation using electrosprayed chitosan microparticles. Aaps Pharmscitech 2018, 19, $3770-3777$. [CrossRef]

43. Pauluk, D.; Padilha, A.K.; Khalil, N.M.; Mainardes, R.M. Chitosan-coated zein nanoparticles for oral delivery of resveratrol: Formation, characterization, stability, mucoadhesive properties and antioxidant activity. Food Hydrocoll. $2019,94,411-417$. [CrossRef]

44. Buanz, A.B.; Belaunde, C.C.; Soutari, N.; Tuleu, C.; Gul, M.O.; Gaisford, S. Ink-jet printing versus solvent casting to prepare oral films: Effect on mechanical properties and physical stability. Int. J. Pharm. 2015, 494, 611-618. [CrossRef]

45. Missaghi, S.; Young, C.; Fegely, K.; Rajabi-Siahboomi, A.R. Delayed release film coating applications on oral solid dosage forms of proton pump inhibitors: Case studies. Drug Dev. Ind. Pharm. 2010, 36, 180-189. [CrossRef] 